Summer 2004

\title{
Localizing Intellectual Property in the Globalization Epoch: The Integration of Indigenous Knowledge
}

Chidi Oguamanam

Dalhousie University

Follow this and additional works at: https://www.repository.law.indiana.edu/ijgls

Part of the Intellectual Property Law Commons, and the International Law Commons

\section{Recommended Citation}

Oguamanam, Chidi (2004) "Localizing Intellectual Property in the Globalization Epoch: The Integration of Indigenous Knowledge," Indiana Journal of Global Legal Studies: Vol. 11 : Iss. 2 , Article 4.

Available at: https://www.repository.law.indiana.edu/ijgls/vol11/iss2/4

This Article is brought to you for free and open access by the Law School Journals at Digital Repository @ Maurer Law. It has been accepted for inclusion in Indiana Journal of Global Legal Studies by an authorized editor of Digital Repository @ Maurer Law. For more information, please contact rvaughan@indiana.edu.

\section{$\Psi$}

JEROME HALL LAW LIBRARY

INDIANA UNIVERSITY

Maurer School of Law
Bloomington 


\title{
Localizing Intellectual Property in the Globalization Epoch: The Integration of Indigenous Knowledge
}

\author{
Chidi Oguamanam
}

INTRODUCTION

The search for appropriate modalities for the protection of indigenous or traditional knowledge ${ }^{1}$ is a subject of contemporary international law and policy discourse. As a primary mechanism for the allocation of rights over knowledge, Western or conventional intellectual property rights (IPRs) provide the concep-

*LL.B. (Ife, Nig.); B.L. (Lagos); LL.M. (Lagos); LL.M.; Ph.D. (British Columbia). Assistant Professor of Law, Dalhousie University, Halifax, Nova Scotia, Canada. At an abstract stage, this paper was the only entry selected for sponsorship by the University of British Columbia for presentation at the 4th Annual Doctoral Students Conference of the Association of Pacific Rim Universities (APRU), August 24-29, 2003, Mexico City, Mexico. I thank the office of the Vice President Academic of UBC for the opportunity. I also thank Professors Maurice Copithorne, Ikechi Mgbeoji, Bob Paterson, and Wes Pue for their intellectual support.

1. In this article, I use the terms "indigenous," "traditional," and "local" knowledge interchangeably without a deliberate attempt to distinguish the terms, save to acknowledge the World Intellectual Property Organization's observation that "[i]ndigenous knowledge fits into the traditional category, but traditional knowledge is not necessarily indigenous." That is to say that all indigenous knowledge is traditional but not all traditional knowledge is indigenous. See World Intellectual Property Organization [WIPO], Report on Fact-Finding Missions on Intellectual Property and Traditional Knowledge 1998-1999 at 26 (2001) [hereinafter FFM].

I note that the term "indigenous peoples" is narrowly construed and often limited to the discourse about the Aboriginal peoples of the American and Australian continents and other culturally distinct groups. However, my use of knowledge, indigenous/traditional/local, is not restricted to only the knowledge forms relating to the narrow category of peoples recognized as indigenous in international law. In this paper, indigenous/traditional/local knowledge refers to knowledge forms in indigenous and other non-Western societies including the umbrella category referred to as "local communities". The latter term alludes to the category of peoples who maintain a close and natural link to the ecosystems and depend on them (with minimum interventions) for their daily subsistence. See generally Surendra Patel, Can IPR Systems Serve the Interest of Indigenous Knowledge?, in Valuing Local Knowledge: Indigenous Peoples and Intellectual Property Rights 305, 307 (Stephen Brush \& Doreen Stabinsky eds., 1996); Michael Blakeney, The Protection of Traditional Knowledge Under Intellectual Property Law, 22 Eur. Intell. Prop. Rev. 251, 252 (2000); Naomi Roht-Ariazza, Of Seeds and Shamans: The Appropriation of the Scientific and Technological Knowledge of Indigenous and Local Communities, 17 Mich. J. INT'L L. 919, 964 (1996) (referring to the introduction of the term "local communities" in international discourse as a design to mitigate the narrow and imprecise nature of the term "indigenous"). 
tual platform in this ongoing inquiry. However, very serious concerns are raised in indigenous and scholarly circles about the suitability of conventional IPRs to the nature of traditional knowledge. ${ }^{2}$ There is almost a consensus that the inadequacy of conventional IPRs in relation to indigenous knowledge compels a look in the direction of a sui generis regime of rights for local knowledge protection. ${ }^{3}$ However, the sui generis proposals are drawn within the rubric of conventional IPRs. ${ }^{4}$ Protection of indigenous knowledge is always considered in relation to the conventional IP system. This is understandable, because in the global economy conventional IPRs are the primary and formal mechanism for the protection of rights over knowledge. However, little regard is given to the fact that virtually all cultures have their own knowledge-protection protocols or conventions. ${ }^{5}$ Fundamentally, such culture-specific protocols are designed to protect knowledge. In that sense, they are functionally akin to Western intellectual property frameworks. Giving due regard to cultural protocols on knowledge protection is different from evaluating such schemes only in terms of their relevance to the conventional IP system. The latter approach undermines the differences in the epistemological narratives between Western and non-Western

2. See, e.g., Patel, supra note 1. Literature in this regard is enormous, but this collection of essays represents the simplest and most convenient reference on the point.

3. See 1 The Crucible II Group, Seeding Solutions: Policy Operations for Genetic Resources: Peoples, Plants and Patents Revisited (2000); 2 The Crucible II Group, Seeding Solutions: Policy Operations for National Laws Governing Control Over Genetic Resources and Biological InNovations (2001).

4. There appears to be no consensus over the nature of the suigeneris concept. While some consider the option as one that must ex necessitate have the likeness of conventional IPRs, others are not similarly inclined or, at best, they are ambivalent about it. See Michael Halewood, Indigenous and Local Knowledge in International Law: A Preface to Sui Generis Intellectual Property Protection, 44 MCGiLL L.J. 953, 961 (1999) (articulating the sui generis notion in terms of a "legal system of protection of knowledge that shares some characteristic with intellectual property law"); see also Dan Leskien \& Michael Flitner, Intellectual Property Rights and Plant Genetic Resources: Options for a Sui Generis System, 6 Issues in Genetic Resources 30 (1997) (arguing that "[ $t$ ]he sui generis system has to be an additional IPR"). Perhaps in the context of the TRIPs Agreement, the idea of a sui generis right being an additional IPR may be more persuasive than under Article 8(j) of the CBD. This article creates open-ended leverage for Contracting Parties to devise regimes for the protection of indigenous and local knowledge forms. A creative device for the protection of knowledge need not necessarily be mainstream IPRs or the like. See generally Peter Drahos, Indigenous Knowledge and Duties of Intellectual Property Owners, 11 InTELL. Prop. J. 179 (1997).

5. This obvious fact was made evident from the results of the WIPO Fact-Finding Missions. See FFM, supra note 1. 
ways of knowing. In virtually all cases, ways of knowing have correlation to the ways of protection, transmission, legitimization and evaluation of knowledge. An acceptable suigeneris mechanism for the protection of local knowledge must be rooted in indigenous episteme. Western IPRs' inability to address the epistemic dichotomy between Western and indigenous ways of knowing is at the root of its failure to meet indigenous peoples' yearnings and aspirations for the preservation of their knowledge and its cultural integrity. This is the basis of the "crisis of legitimacy in the intellectual property system." 6

Spotlighting traditional medicine and the patent regime, this article first highlights elements of the debate surrounding the use of conventional IPRs for the protection of traditional knowledge. It underscores the acknowledged controversy and inadequacies of that approach, and draws attention to the ongoing effort to integrate indigenous knowledge-protection protocols into the IP project. ${ }^{7}$ In contrast to the hitherto one-sided focus on the conventional IP system, extant efforts look to draw in knowledge-protection schemes and protocols that exist within indigenous and non-Western customary practices and jurisprudence. These developments mark a more significant step toward a realistic approach to the protection of indigenous knowledge than is offered by the conventional IP system or sui generis options based on that system. This approach depicts a cross-cultural outlook on IPRs. ${ }^{8}$ The article then presents an overview of the trend at the World Intellectual Property Organization (WIPO) and the Convention on Biological Diversity (CBD).

Finally, the article examines the perceived conflict between the centrifugal focus of the attempt to integrate customary regimes for knowledge protection into the IP discourse, and the phenomenon of globalization as symbolized by the

6. See Rosemary J. Coombe, The Recognition of Indigenous Peoples' and Community Traditional Knowledge in International Law, 14 St. Thomas L. Rev. 275, 285 (2001).

7. Perhaps the most significant development in this direction is the establishment in 1996 at the Third Conference of Parties (COP) Meeting of the CDB (Buenos Aires, Argentina, 1-15 November 1996) of an inter-sessional process for advancing work on the implementation of Article $8(j)$ of the CBD. This idea was first muted at the Second COP in 1994. The inter-sessional process is the precursor to the Working Group on Article 8(j). The next major trend in the cross-cultural approach is the WIPO's 1997 Global Intellectual Property Issues (GIPI) initiative. See infra Part III for more on the GIPI.

8. See Coombe, supra note 6 , at 284 (evaluating the cross-cultural initiatives from an international law-making perspective). 
Trade Related Aspects of Intellectual Property Rights (TRIPs) Agreement. ${ }^{9}$ The fact that the thrust of the effort to integrate indigenous knowledge-protection protocols into the IP discourse emphasizes the local poses a potential conflict to the current globalization initiative, especially in the IP arena. Even though TRIPs is an attempt to globalize IP, it does not change the status of IP as a subject under national jurisdiction. The effort to integrate knowledge-protection regimes from indigenous and local communities into the IP legal scheme could well have global ramifications. In effecting the legal protection of traditional knowledge, national governments would indeed be within their legitimate powers, both under the TRIPs Agreement and their commitments to various international instruments on the protection of indigenous peoples. ${ }^{10}$

The need to integrate indigenous knowledge-protection protocols into IP discourse is a consequence of an indigenous renaissance and resistance that has yielded a logic of epistemological pluralism. Under this pluralism, indigenous holistic and subjective understanding of phenomena or ways of knowing compete for a space within knowledge-protection jurisprudence. This article argues that contrary to popular accounts, this competition is part of the globalization experience. The notion of integrating indigenous knowledge-protection protocols into the IP agenda does not necessarily conflict with the phenomenon of globalization, as many would think. Nonetheless, the integration project is at a nascent stage. It will surely raise a number of questions and concerns. Its relationship with globalization, with which this paper is concerned, is only one of the many issues that confront the cross-cultural momentum on IPRs.

9. See generally WTO Agreement on Trade Related Aspects of Intellectual Property Rights, April 15, 1994, reprinted in 33 I.L.M.1197 (1994).

10. See generally International Labour Organization, Convention Concerning Indigenous and Tribal Peoples in Independent Countries, June 27, 1989, reprinted in 28 I.L.M. 1382 (1989); Convention on Biological Diversity, June 11, 1992, reprinted in 31 1.L.M. 818 (1992). See generally International Bill of Rights: Universal Declaration of Human Rights, G.A. Res. 217 (III), U.N. GAOR 3d. Sess., Supp. No. 13, at 71, U.N. Doc. A/810 (1948); International Covenant on Civil and Political Rights, Dec. 19, 1966, 999 U.N.T.S. 171; International Covenant on Economic, Social and Cultural Rights, Dec. 16, 1966, 993 U.N.T.S. 3. 


\section{Indigenous Knowledge and Intellectual Property: The Fitness Question}

There is a need to reconcile indigenous knowledge with conventional IPRs. This need is informed by the desire of indigenous peoples to benefit from their knowledge, while preserving its integrity and stemming the tide of its appropriation by external interests. ${ }^{11}$ Apart from being integral to the indigenous quest for self-determination, this need continues to rise because of the growing value of indigenous knowledge in different areas of scientific, cultural, economic, and commercial endeavors. The traditional knowledge of non-Western peoples is implicated in virtually every front of human endeavor in the global arena, including, but not limited to, trade and economic empowerment, food, agriculture, the environment (especially conservation of biodiversity), health, human rights, ${ }^{12}$ and cultural policy. The explosion in biotechnology and the emergence of the global knowledge and information society ${ }^{13}$ in the twentieth and twentyfirst centuries has further accentuated the value of local knowledge.

The following are samples of the contribution of traditional knowledge in the contemporary global society: Allowing for certain industry assumptions, when drug researchers supplement conventional Western practices with the use of indigenous medical plant knowledge, the possibility of "developing at least

11. For a detailed rationale for the protection of indigenous knowledge, see Coombe, supra note 6 at $278-80$.

12. While the connection between traditional knowledge and trade, economic empowerment, food, agriculture, biodiversity conservation, and cultural policy issues may seem obvious, its linkage to the human rights of indigenous peoples may not be quite as obvious. There is, however, little doubt that in a general sense, the enumerated issues have human rights undertones in so far as they jointly or severally have implications for the survival of indigenous peoples. For a thorough perspective on the relationship between indigenous knowledge, IPRs and human rights of indigenous peoples, see generally Rosemary J. Coombe, Intellectual Property, Human Rights and Sovereignty: New Dilemmas in International Law Posed by the Recognition of Indigenous Knowledge and The Conservation of Biological Diversity, 6 Ind. J. Global Legal Stud. 59 (1998) [hereinafter New Dilemmas]; see also Justin VanFleet, Protecting Knowledge, Hum. Rts. Dialogue, Spring 2003, at 18-19.

13. See Protection of Traditional Knowledge: A Global Intellectual Property Issue, WIPO Roundtable on Intellectual Property and Traditional Knowledge at 2, WIPO/IPTK/99/2 (Oct. 22, 1999), available at http://www.wipo.inv; see also Peter Drahos, Indigenous Knowledge, Intellectual Property and Biopiracy: Is a Global Bio-Collecting Society the Answer?, 22 Eur. Intell. Prop. Rev. 245 (2000) [hereinafter Bio-Collecting Society] (alluding to the notion of a global knowledge society); see generally Peter Drahos \& John Braithwaite, Information Feudalism, Who Owns the KNOWLEDGE ECONOMY? (2002). 
one marketable pharmaceutical from 1,000 samples grows from 22 percent to 78 percent or three and half times." ${ }^{14}$ Similarly, when using traditional knowledge, the efficiency of screening plants for medicinal properties increases by more than 400 percent. ${ }^{15}$ The annual market value of pharmaceutical products derived from tropical rainforest plant-based medicinal knowledge of indigenous peoples exceeds $\$ 32$ billion. ${ }^{16}$ Traditional healers have employed most of the 7,000 natural compounds used in modern medicine today for centuries. Twenty five percent of American prescription drugs contain active ingredients derived from indigenous knowledge of plants. ${ }^{17}$ The same percentage of all prescription drugs comes from rainforest plants, and seventy-five percent of these have been gathered from information provided by indigenous peoples. ${ }^{18}$ All over the world, especially in the United States, a number of pharmaceutical companies are dedicated to drug discovery based exclusively on indigenous or so-called "shamanic" knowledge."

14. Curtis M. Horton, Protecting Biodiversity and Cultural Diversity Under Intellectual Property Law: Toward a New International System, 10 J. EnvtL. L. \& Litig. 1, 5 (1995).

15. See Michael Balick, Ethnobotany and the Identification of Therapeutic Agents from the Rainforest, in Bioactive Compounds From Plants 22-39 (Derek J. Chadwick \& Joan Marsh eds., 1990).

16. See Darrel Posey \& Graham Dutfield, Beyond Intellectual Property: Toward Traditional Resource Rights for Indigenous Peoples and Local Communities 34 (1996); see also John Mugabe, Managing Access to Genetic Resources, in Access to Genetic Resources: Strategies for Sharing Benefits 6 (Mugabe et al. eds., 1997).

17. See Study on the Protection of Cultural and Intellectual Property of Indigenous Peoples: Report of Erica-Irene Daes, Special Rapporteur, Commission on Human Rights, Sub-Commission on Prevention of Discrimination Against Minorities, 45th Sess., Agenda Item 14 at 23, U.N. Doc.: E/ CN.4/sub.2/1993/28 (1993); see also Marie Battiste \& James Y. Henderson, Protecting Indigenous Knowledge and Heritage: A Global Challenge 125-26 (2000); see also William McKinley Klein, Jr., The Role of Botanical Gardens and Arboreta in Traditional Medicine: A Personal Reflection and Case Study, in Medicinal Plants: Their Role in Health and Biodiversity 120, 128 (Timothy R. Tomlinson \& Olayiwola Akerle eds., 1998) [hereinafter Medicinal Plants].

18. See Biotechnology and Medicinal Plants, Rural Advancement Fund International (RAFI Communiqué, now ETC Group), March, 1989; see also Andrew Gray, The Impact of Biodiversity Conservation on Indigenous Peoples, in Vandana Shiva et al., Biodiversity: Social and Ecological Perspectives 59, 67 (1991).

19. See Lisa A. Conte, Shaman Pharmaceuticals' Approach to Drug Development, in Medicinal Resources of the Tropical Forest: Biodiversity and Its Importance to Human Health 94-100 (Michael J. Balick et al. eds., 1996); see also Edgar J. Asebey \& J.D. Kempenaar, Biodiversity Prospecting: Fulfilling the Mandate of the Biodiversity Convention, 28 VAND. J. TRAnsnat'L L. 703, 730-36 (1995). 
Notwithstanding the sterling contributions of indigenous knowledge toward humanity's quest for a better society in different areas, the custodians and practitioners of that knowledge are left out from the benefits accruing thereto. ${ }^{20}$ Beyond material benefit, such appropriation presently threatens the cultural integrity of indigenous knowledge, principally because the dominant knowledgeprotection and reward mechanism is the Western intellectual property regime, which is not designed to account for or accommodate epistemic narratives other than Western science. There are several ways in which conventional IPRs are said to be a mismatch for indigenous knowledge forms. ${ }^{21}$ None of the arguments represents the complete picture. Indeed, for each of them, there are counterarguments. For the present purpose, I state the central themes of the arguments in very simple terms and deliberately exclude the counterarguments that have been sufficiently discussed in the literature.2 The debate over the fitness of con-

20. For example, Posey avers that less than 0.001 percent of profits from drugs discovered by use of indigenous knowledge have ever accrued to indigenous peoples. See Michael R. Dove, Center, Periphery and Biodiversity: A Paradox of Governance and a Developmental Challenge, in VAluing Local KNOWLEDGE, supra note 1 , at 55 . Apart from sharing in the profits, generally, indigenous peoples are not guaranteed access to the benefits of research projects that were based on their knowledge and insight.

21. But Coombe argues that this may not be entirely accurate. According to her, "different perspectives on the nature of culture tend to lead to the adoption of diverging positions on the viability of further extending intellectual property protections" to indigenous knowledge. New Dilemmas, supra note 12 , at 77.

22. See, e.g., New Dilemmas, supra note 12, at 59; Duties of IP Owners, supra note 4, at 186-87; John Frow, Public Domain and Collective Rights in Culture, 13 InTell. Prop. J. 39, 51 (1998); Ikechi Mgbeoji, Patents and Traditional Knowledge of the Uses of Plants: Is a Communal Patent Regime Part of the Solution to the Scourge of Bio Piracy?, 9 Ind. J. Global Legal Stud. 163, 183 (2001); Anil K. Gupta, Getting Creative Individuals Their Due: Framework for Operationalizing Article 8(j) and Article 10(c), Paper submitted to the Convention on Biological Diversity Secretariat, Montreal (1996), at http://csf.Colorado.edu/sristi/papers/getting.html (last visited Feb. 10, 2004); Graham Dutfield, Intellectual Property Rights, Trade and Biodiversity: Seeds and Plant Varieties 120-2l (2000); Mohammed Khalil, Biodiversity and Conservation of Medicinal Plants: Issues from the Perspectives of the Developing World, in Intellectual Property Rights and Biological Diversity Conservation: An Interdisciplinary Analysis of the Values of Medicinal Plants 240 (Timothy Swanson ed., 1995); Posey \& Dutfield, supra note 16; Intergov'tal Comm. on Intell. Prop. and Genetic Resources, Traditional Knowledge and Folklore (IGC-GRTKF), Survey on Existing Forms of Intellectual Property Protection for Traditional Knowledge-Preliminary Analysis and Conclusions, WIPO Doc. WIPO/GRTKF/IC/2/9, at 2 (Dec. 3, 2001), available at http:// www.wipo.ind (last visited Feb. 10, 2004); Intergov'tal Comm. on Intell. Prop. and Genetic Resources, Traditional Knowledge and Folklore, Elements of Sui Generis System for the Protection of Traditional Knowledge, WIPO Doc. WIPO/GRTFK/IC/8/8, at 2, 13 (March 29 2002) [hereinafter Elements of Sui Generis], available at http://www.wipo.int/ (last visited Feb. 10, 2004). 
ventional IP to indigenous knowledge forms is an ongoing one. Given the consensus that conventional IP does not satisfy the peculiarity of indigenous knowledge, the most important question today appears to be how to mitigate this state of affairs and by employing what manner of a suigeneris IP model.

The first argument is that indigenous knowledge is usually community property derived from communal effort. ${ }^{23}$ Each member of the community is thus entitled to share in it, and none may exercise an exclusive claim, as the concept of conventional IPRs requires. ${ }^{24}$ Generally, individualism is the model for entitlement to IPRs within the conventional system. ${ }^{25}$ An ownership structure based on the community stands in sharp contrast to a knowledge-protection scheme that reifies the individual as the primary harbinger or agent of intellectual advancement.

The second argument is based on the concept of legal personality. Because most indigenous societies are based on a communal or collective organizational structure, they are said to lack the requisite legal or juridical personality on the basis of which they can hold IPRs. Under conventional IPR theory, juristic persons in the form of natural and corporate entities are the only appropriate holders of rights in knowledge. ${ }^{26}$

23. See Christine Haight Farley, Protecting Folklore of Indigenous Peoples: Is Intellectual Property the Answer?, 30 Conn. L. Rev. 1, 30 \& n.117 (1997) (noting that with regard to indigenous artwork, "most art work is essentially executed by a group. The making of art in the indigenous community is not the lonely, secluded, individual process idealized in the west, but instead a group process in which many people participate at various levels."); see also VanFleet, supra note 12, at 18.

24. Intellectual property involves the practice of taking public goods and information into the private domain, or what is described as imposing "private toll-gates" or "fences" around knowledge and information that belongs to the public domain. See New Dilemmas, supra note 12, at 9293. See generally Justin Hughes, The Philosophy of Intellectual Property, 77 GEo. L. J. 287 (1988) (discussing philosophical justifications for the concept of intellectual property); Jeremy Waldron, From Authors to Copiers: Individual Rights and Social Values in Intellectual Property, 68 CHI-KeNT L. Rev. 841 (1993) (providing practical justifications for the protection of intellectual property); Keith Aoki, Neocolonialism, Anticommons Property, and Biopiracy in the (Not-So-Brave) New World Order of International Intellectual Property Protection, 6 I ND J. Global Legal Stud. 11, 26-27 (1998) (discussing the pitfalls of community property in an IPR system).

25. See Marci Hamilton, The TRIPS Agreement: Imperialistic, Outdated, and Overprotective, 29 VAnd. J. TRansnat'L L. 613, 617 (1996); see also Mgbeoji, supra note 22, at 182. Until recently, WIPO had insisted on individual authorship as a prerequisite for IP protection. See New Dilemmas, supra note 12 , at $76 \&$ n. 68 .

26. See Ikechi Mgbeoji, Patents and Plants: Re-thinking the Role of International Law in Relation to the Appropriation of Traditional Knowledge of Uses of Plants 373 (2001) (unpublished S.J.D. Thesis, Dalhousie University) (on file with author). 
The third argument issues from the nature of indigenous knowledge, rather than from the nature of indigenous social structures. Indigenous bio-cultural knowledge is said not to constitute original information. ${ }^{27}$ Indigenous knowledge represents historical information collected from time immemorial in an incremental fashion. Such information is part of the "intellectual commons." 28 As such, it is not considered new. Indeed, it is said to be in the public domain as common heritage of mankind ${ }^{29}$ and ought to be freely available to all people who may require them at any point in time..$^{30}$ Being in the public domain as a common heritage, the argument goes, indigenous knowledge forms do not qualify for IP protection.

Other arguments against the suitability of conventional IPRs to indigenous knowledge are based on practical and logistical considerations. The first is that because traditional knowledge exists within oral culture, there is always difficulty in transforming it into written form. This is evident in the context of the technical nature of a patent specification, which is a material condition for the grant of a patent. Similar to this is the publication requirement. For traditional knowledge to be part of conventional IP, it must be published in written form. In the process of granting a patent, prior art is determined not by oral narrative, but by publication in written form.

A second practical consideration relates to the fixed term of IPRs. Most IP regimes, including patents and copyrights, are premised on a fixed term. How-

27. Patents and copyright regimes are granted, inter alia, on the basis of the originality of the work in question. Whereas copyright protects authorship and concomitant notion of originality, the patent regime emphasizes the absence of prior art and the novelty or newness of invention. See, e.g., Feist Publ'ns, Inc. v. Rural Tel. Serv. Co., 499 U.S. 340, 345 (1991); see also Farley, supra note 23 , at 18 .

28. Common heritage of mankind can be defined as "a global entity constructed by the collective labours of all humanity over all time." See Duties of IP Owners, supra note 4, at 182.

29. See Stephen Brush, Whose Knowledge, Whose Genes, Whose Rights?, in Valuing Local KNOWLEDGE, supra note 1, at 3 (arguing that knowledge and biological resources of farmers, herbalists, et cetera have historical status as "common heritage held in trust for the public good"). For perspectives on the evolution of the common heritage principle, see Rudiger Wolfrum, The Principle of Common Heritage of Mankind, 43 Heidelberg J. INT'L L. 312 (1983); see also Stephen Gorove, The Concept of Common Heritage of Mankind: A Political Moral and Legal Innovation, 9 SAN Diego L. Rev. 390 (1972) (exploring the various influences on the common heritage of mankind). See generally Stephen Brush, Is Common Heritage Outmoded?, in Valuing Local KnowlEDGE, supra note 1, at 143 [hereinafter Is Common Heritage Outmoded] (exploring the common heritage principle in the context of biological resources).

30. See Is Common Heritage Outmoded?, in Valuing Local Knowledge, supra note 1, at 149. 
ever, traditional knowledge is an immemorial and trans-generational experience that evolves incrementally. ${ }^{31}$ Indeed, in a sense, indigenous knowledge is the antithesis of tenured knowledge or property. ${ }^{32}$ When and where it begins and ends are indeterminate.

A third constraint harps on the lack of financial power in indigenous communities to register and service IPRs, ${ }^{33}$ particularly the expensive patenting process. Coupled with this is the fact that most high profile IP infringements occur across borders. It would require additional but currently nonexistent financial strength for indigenous communities to successfully police infringement of these rights. Fourth, when indigenous knowledge is retrofitted into a sophisticated "scientific" narrative, it becomes Herculean to establish acts of appropriation or misappropriation. ${ }^{34}$ Many cases of appropriation of local knowledge occur within a global network beyond the reach and sophistication of many indigenous communities.

The last major point is not an objection in the strict sense. It is an attempt to characterize the nature of IPRs. Most objections over the applicability of IPRs to indigenous knowledge are based on the concept or theoretical foundation of

31. See Kamal Puri, Is Traditional or Cultural Knowledge a form of Intellectual Property?, paper presented at the Oxford University Intellectual Property Research Centre Seminar (January 18, 2000), at http://www.oiprc.ox.ak.uk/EJWP0100.pdf (last visited Jan. 31, 2004); see also UNESCOWipo, Model Provisions for National Laws on the Protection of Expressions of Folklore Against Illicit Exploitation and Other Prejudicial Actions, reprinted in 16 Copyright Bull. $62(1982)$.

32. According to Farley, "It]his limited term of protection means that most folkloric works [for instance] may already be in the public domain," even assuming they satisfy other requirements for copyright protection. Farley, supra note 23, at 18. But see Robert K. Paterson \& Dennis Karjala, Looking Beyond Intellectual Property in Resolving Protection of the Intangible Cultural Heritage of Indigenous Peoples, 11 CARdozo J. INT'L \& Comp. L. 633, 668 (2003) (arguing that protection of traditional knowledge ought to accommodate the imperative to maintain a "rich and growing public domain that promotes basic values of free thought and expression").

33. For instance, one of the advantages of the Global Bio-Collecting Society (proposed by Peter Drahos) is to mitigate the cost of monitoring the use and appropriation of indigenous knowledge, which most indigenous communities lack the resources to do effectively. See Drahos, supra note 13 , at 248 .

34. As a solution to this quagmire, Peter Drahos proposes a Global-Bio Collecting Society to "help indigenous groups to solve the problem of international free-riding by offering them some prospect that the rights over their knowledge would be recognized by companies irrespective of where those companies were located." Id. at 249 . Similarly, the momentum toward a global database of indigenous knowledge is to make the same available to patent examiners in order to check bogus applications based on the appropriation of prior knowledge. See VanFleet, supra note 12, at 18. 
conventional IPRs. Intellectual property is a market instrument most suited to capitalist ideology. Chiefly, IPRs are capitalist creations, designed to serve the market economy and advance commercial interests as a matter of priority over cultural sensitivities. ${ }^{35}$ In advancing commercial interests, IP facilitates commodification of all things, including indigenous bio-cultural and ecological experiences, in an industrial fashion. ${ }^{36}$ Fixed and commodified as a physical manifestation of ideas, knowledge that is often viewed as sacred is measured on an economic scale of values and auctioned accordingly. For indigenous peoples, this tendency to commodify and commercialize, as facilitated by IPRs, is not an acceptable way of dealing with their sacred knowledge and ecological experience. For them, the sanctified communion and experience that they share with other living beings or partners cannot be subjected to an economic scale of values through commodification. ${ }^{37}$ The capitalist orientation of conventional IPRs is in apparent conflict with the communal nature of ownership and the socio-cultural structure of indigenous societies. ${ }^{38}$ Strict individualistic constructs of property in the Western mold do not fit into indigenous ideals. ${ }^{39}$

35. According to David Vaver, "[t]he underlying aim is to protect ideas of 'practical application in industry, trade and commerce." See David Vaver, Intellectual Property Law: Copyrights, Patents, Trademark 119 (1997). Chartrand sees IPRs as designed to drive intellectual works into the market place. For him, they operate more as "instruments of commerce than of culture." See Harry Hillman Chartrand, Intellectual Property in the Global Village, at http://www.usask.ca/ibrary/ (last visited Mar. 18, 2002). Attempts by indigenous cultures to use IP as a vehicle for cultural expression/resistance, or to engage in a dialogic exchange with the dominant culture are unevenly matched by aggressive employment of IPRs by the dominant culture through the use of embedded privileges. See Rosemary J. Coombe, The Cultural Life of Intellectual Property Rights: Authorship, Appropriation, and the Law (1998) [hereinafter Cultural Life of IP]; Rosemary Coombe, Critical Cultural Studies, 10 Yale J.L. \& Human. 463 (1998); see also Farley, supra note 23 , at 8 .

36. See Mark Ritchie et al., Intellectual Property Rights and Biodiversity: The Industrialization of Natural Resources and Traditional Knowledge, 11 St. John's J. Legal Comment 431 (1996); see also Duties of IP Owners, supra note 4, at 196 (acknowledging the objection to commodification).

37. See Norman W. Spaulding III, Commodification and It Discontents: Environmentalism and the Promise of Market Incentives, 16 Stan. ENvT'L L.J. 294, 311 (1997) (on the intricacies of applying neoclassical economic or free market approaches to the realm of environmental protection vis. à vis. a command and control option).

38. See Brush \& Stabinsky, in Valuing Local. Knowledge, supra note 1, at 3.

39. Describing IPRs as tools of capitalism, Brush and Stabinsky warn against their "potential harm in the arena that involves indigenous peoples, peasants..." Continuing, they argue that "[i]ntellectual property for indigenous knowledge, commoditizing knowledge and plant life, and biological prospecting are part of a rush to capitalism in times of aversion to common solutions to public problems." Id. 
Another conceptual issue relating to the nature of conventional IP is its connection to Western science. As noted earlier, ways of protecting knowledge correlate with the manner in which knowledge is generated. The patent regime, for instance, is designed to recognize, legitimize and consequently empower Western scientific narrative (in the sense of convention or practice). It gives no regard to cultural accounts of science outside the Western paradigm. Conditions for the grant of patents, especially in the bio-cultural context, are based on Western scientific criteria. The TRIPs Agreement sets out minimum conditions of patentability for global application. As demonstrated in the next section, for indigenous knowledge forms to be patented, they must undergo the process of filtration or scientific scrutiny in order to bring them into conformity with the Western episteme. ${ }^{40}$

\section{A. Patents in the Traditional Medicine Context}

The World Health Organization (WHO) defines health as "a state of complete physical, mental and social well-being and not merely the absence of disease or infirmity." ${ }^{41}$ This notion of health is broad. It inherently accommodates the biomedical and psychosocial paradigmatic approaches to health. In general terms, those two paradigms correspond to the epistemological templates in which the health care cultures in Western and non-Western societies are fostered. ${ }^{42}$ Without question, WHO's definition is consistent with the holistic conception of health in many non-Western indigenous or traditional communities. ${ }^{43}$

The indigenous worldviews and understanding of phenomena are associated with indigenous health care cultures, including their theories of health and ill

40. See Arun Agrawal, On Power and Indigenous Knowledge, in Cultural and SpIRITual Values of Biological Diversity: A Complementary Contribution to the Global Bioniversity Assessment 178 (D. Posey ed., 1999); Lester Yano, Comment, Protection of the Ethnobiological Knowledge of Indigenous Peoples, 41 UCLA L. Rev. 443, 462 (1993). See generally Battiste \& HeNDERSON, supra note 17.

41. See Constitution of the World Health Organization, opened for signature July 22, 1946, 62 Stat. 2679, 14 U.N.T.S. 185.

42. See Charles M. Good, Ethnomedical Systems in Africa: Patterns of Traditional MediCINe in RuRal and Urban KenYa 13-15 (1987) (contrasting the Western biomedical health paradigm with the non-Western psychosocial health paradigm); see also Collins Airhihenbuwa, Health and Culture: Beyond the Western Paradigm (1995); George Murdock, Theories of Illness: A World Survey (1980).

43. See Good, supra note 42, at 15. 
health, diseases and afflictions, and suffering and other forms of emotional and physical disequilibria. ${ }^{44}$ Because of their psychosocial and psychosomatic thrust, ${ }^{45}$ traditional therapeutic interventions investigate health concerns from the bundle of social and spiritual relationships the individual has with society. The health and well-being of an individual is associated with the need for harmony in relationships, including the family, community, spiritual, and even metaphysical and other linkages. ${ }^{46}$ In this holistic approach to health, spiritual, emotional, and social factors constitute the focus of traditional diagnosis and therapeutic intervention. ${ }^{47}$ The essence of therapy is the restoration of the sick to harmony with every relevant segment of her social interactions for optimum existence. ${ }^{48}$

Traditional medicine is a very important genre of indigenous knowledge. It is the vehicle for the propagation of indigenous medical culture. That culture is acknowledged as a complete health system, reflecting "[a] patterned, interrelated body of values and deliberate practices, governed by a single paradigm of meaning, identification, prevention and treatment of sickness." "[T]

44. That health care practices and culture have a mutually re-enforcing and inseparable affinity is affirmed in medical anthropology, medical geography, and studies in sociology. See, e.g., Good, supra note 42; Airhinenduwa, supra note 42; Healing Logics: Culture and Medicine in Modern Belief Systems (Erica Brady ed., 2001); Cecil G. Helman, Culture, Health and Illness (2000); Arthur Kleinman, Patients and Healers in the Context of Culture (1980).

45. See Mamadou Koumare, Traditional Medicine And Psychiatry In Africa, in Traditional Medicine and Health Care Coverage: A Reader for Health Administrators and Practitioners 25 (Robert H. Bannermann et al. eds., 1983) [hereinafter Traditional Medicine and Health Care]; see also Kenneth R. Pelletier, Psychosomatic Approaches to Healing in Folk Medicine and Herbal Healing 30, 31 (George G. Meyer et al. eds., 1981) [hereinafter Folk Medicine].

46. See Robert L. Bergman, The Physician and Folk Healer, in Folk Medicine, supra note 45, at 88; see also Carmel Goldwater, Traditional Medicine in Latin America, in Traditional Medicine \& Health Care, supra note 45, at 38; McKinley Klein, Jr., in Medicinal Plants, supra note 17, at 121 (arguing the beneficial effects of gardens to human health).

47. See John Burton, Public Health, in Traditional Medicine \& Health Care, supra note 45, at 108; see also John S. Mbiti, African Religions \& Philosophy 169 (1969); O. Ampofo \& F.D. Johnson-Romauld, Traditional Medicine and Its Role in the Development of Health Services in Africa, WHO, Regional Office for Africa, 25th and 27th Sess., Brazzaville, Congo, Background Papers for the Technical Discussions at 40 (1978) (supporting the view that the conception of disease in African therapeutic culture is not necessarily organismic dysfunction; rather, and more importantly, it emphasizes the notion of disharmonious relationships with natural and social forces).

48. O.F. Onoge, Capitalism and Public Health: A Neglected Theme in Medical Anthropology of Africa, in Topias and Utopias in Health 220 (Stanley R. Ingman \& Anthony E. Thomas eds., 1975), cited in Good, supra note 42, at 15.

49. Irwin Press, Problems in the Definition and Classification of Traditional Medical Systems, 14B Soc. Scr. \& MED. 45, 47 (1980), quoted in Good, supra note 42, at 23. 
medicine represents the authoritative delivery of a culture's cumulative experience with the healing arts. ${ }^{" 50}$ Institutional and scholarly definitions of traditional medicine underscore its ramification as a complete health system. For instance, WHO defines traditional medicine as: "the sum total of the knowledge, skills and practices based on the theories, beliefs and experiences indigenous to different cultures, whether explicable or not, used in the maintenance of health, as well as in the prevention, diagnosis, improvement or treatment of physical and mental illness. ${ }^{51}$ Charles Good and other leading scholars do not disagree. For them, traditional medicine is:

[T] he total body of knowledge, techniques, for the preparation and use of substances [including belief systems], measures and practices in use, whether explicable [to Western science] or not, that are based on ... personal [and communal] experience and observations handed down [or evolving] from generation to generation, either verbally or [sic] in writing, and are used for the diagnosis, prevention, or elimination of imbalances in physical, mental or social well being. ${ }^{52}$

In contrast, the Western biomedical approach to illness is a strict scientific endeavor in the narrow sense of Western science. The psychosocial and psychosomatic dimensions are not its primary concerns. Boosted by the germ theory, Western biomedicine narrowly considers disease and illness as biological

50. Good, supra note 42, at 2.

51. WHO, General Guidelines for Methodologies on Research and Evaluation of Traditional Medicine, WHO Doc. WHO/EDM/TRM/2000, available at http://www.who.int/ (last visited June 3, 2003); see also Ong Chui Koon, Intellectual Property Protection of Traditional Medicine and Treatments in Malaysia, in Intellectual Property Aspects of Ethnobiology 155, 157 (Michael Blakeney ed., 1999) [hereinafter IP and Ethnobiology]; WHO, Traditional Medicine Strategy 2002-2005, at 7 (2002) [hereinafter Traditional Medicine Strategy] (defining traditional medicine "as including diverse health practices, approaches, knowledge and beliefs incorporating plant, animal and/or mineral based medicines, spiritual therapies, manual techniques and exercises applied singularly or in combination to maintain well-being, as well as to treat, diagnose or prevent illness.").

52. Koumare, supra note 45 , at 25. 
processes. ${ }^{53}$ Organismic, Newtonian and mechanical outlooks are the principal diagnostic approaches to medical conditions. In this context, the cause of illness must be traced to an organic agent, which must be targeted and isolated for therapeutic intervention. Consistent with this organismic and mechanical approach, the human body is considered a complex whole made up of parts. ${ }^{54}$ The causal agent must be identified from the specific part of the body that is afflicted. In this regard, the allopathic tradition is one with a multiplicity of professional specialties ${ }^{55}$ with claims to oraganismic expertise either in reference to a given disease as a causal agent, or to human organs as sites of affliction and intervention. Here, unlike in the traditional therapeutic context, the patient's body, not her complex social and psychosomatic condition, is the principal site of medical intervention and experimentation. ${ }^{56}$

From the above, it is clear that traditional medicine and Western biomedicine are two independent health systems. Each operates from a diverse body of values and practices supervised by a different epistemological regime. To bring traditional medicine practices within the cover of the protection offered by IPRs, especially patents, we have to confront the epistemological problem that arises. The patent regime of IPRs is designed to accommodate and legitimize epistemological narratives rooted in Western science and technology. Because knowledge-protection regimes are products of the epistemological traditions in which knowledge is generated, it appears that the only condition in which traditional medicine could benefit from the patent regime is forced assimilation into Western scientific appraisal.

Similar to the narrow organismic and fragmentary nature of biomedicine, the patent regime insists on a detailed analysis of information or data according to their scientific relevance. Like biomedicine, it discounts all knowledge forms or information that cannot be interpreted in a scientific or technological sense. It

53. See Murdock, supra note 42, at 9 (defining the natural theory of illness as one whose process must be explicable to medical science); see also Deborah Oates Erwin, The Militarization of Cancer Treatment in American Society, in Encounters with Biomedicine: Case Studies in Medical ANthropology 201, 202 (Hans A. Baer ed., 1987).

54. See Helman, supra note 44, at 81-82.

55. See John J. Canary, Modern Allopathic Medicine and Public Health, in Traditional Medicine \& Health Care, supra note 45, at 90, 92.

56. John Canary, writing in relation to the allopathic medical system observes that "[i]n the very best medical establishments, the student or the doctor is encouraged to consider his activity in regard to each patient also as a research project." $I d$. at 98 . However, I do not personally think that this undermines the humanitarian instinct of allopathic practitioners. 
emphasizes specificity of information. In medico-pharmaceutical contexts, patent demands the identification, isolation, synthesizing or purification of active substances, as well as the physiological or scientific ramification of a given therapeutic intervention. This is not only irrelevant in the indigenous context, ${ }^{57}$ but also more than indigenous epistemological tradition could satisfactorily explain or rationalize. Unless indigenous therapeutic experience is expressed and proven in a Western scientific manner, it would not be protected by the patent regime. Even if patent protection may be achieved, invariably, it would be at the expense of a forced epistemic assimilation of traditional knowledge into the dominant scientific narrative. As a result, epistemic pluralism is compromised. In other words, indigenous contributions to the global basket of knowledge-in this case medical knowledge, including indigenous cultural integrity-will be forced to give way to the unipolar epistemic hegemony of Western biomedicine. As if with this scenario in mind, Agrawal warns: "Many wish to use international patents system to protect the interests of the poor and the marginal. The danger is that such activities on behalf of indigenous knowledge can become ends in themselves, and the interests of the marginal can become sidelined." 58 Western episteme sustains the patent institution and practice. Extended to traditional medicine, the patent system works to rid local people of their oral tradition and culture of health care. The imperative for medical pluralism is premised on the fact that neither Western biomedicine, nor any medical system for that matter, has a monopoly of solution to all human afflictions. New diseases and afflictions continue to inundate mankind, thus necessitating the need to keep all options open in the search for viable treatment.

A prominent public health law scholar, David Fidler, has noted that in the globalization era, traditional medicine is in imminent danger of demise. ${ }^{59}$ According to Fidler, the attempt to regulate traditional medicine and integrate it into mainstream public health for better health care delivery is "a move to Westernize traditional medical practices by moving them onto a firmer scientific and legal basis." ${ }^{60}$ Fidler associates this trend with cultural erosion, which is capable

57. See Yano, supra note 40 , at 460 (arguing that the knowledge required in the native context is the identity of the plant). This is, however, in addition to other complex, context-specific rituals.

58. Agrawal, supra note 40 , at 178.

59. See David P. Fidler, Neither Science Nor Shamans: Globalization of Markets and Health in the Developing World, 7 Ind. J. Global Legal Stud. 191, 223 (1999).

60. Id. at 220 . 
of eventually making traditional medicine irrelevant in developing countries. ${ }^{61}$ In addition to Fidler's fears, perhaps more than the impact of direct policy interventions in the globalization era, the idea of IP, especially the patent regime in relation to traditional medicine, represents the most potential threat to the future of that sensitive genre of indigenous knowledge.

By now, it is clear that the point is not whether IP could be applied to traditional medicine. Without question, this may be possible subject to a forced epistemological transformation of traditional medicine into Western-style scientific narrative. Other remaining peripheral hurdles to applying conventional IP to traditional medicine can be fixed. For instance, duration of rights, legal status of indigenous communities, definition or redefinition of prior art, can all be negotiated to accommodate the peculiarities of indigenous knowledge. The epistemic schism between indigenous and Western ways of knowing that the patent regime reinforces is perhaps the most critical aspect of the IP debate, to which most propositions for sui generis IP options have not given the rigorous consideration that it deserves. ${ }^{62}$ To satisfactorily address this epistemic logjam, it is proposed that a sui generis or alternative IP regime must not necessarily have to be patterned after conventional IPRs. It must be a regime that takes cognizance of the epistemological milieu in which indigenous knowledge forms are generated. This introduces us to ongoing attempts to incorporate indigenous knowledge-protection protocols into the IP debate.

\section{B. The Integration of Indigenous Knowledge-Protection Protocols}

Mechanisms for the protection, legitimization, and reward for knowledge are products of the cultural contexts in which knowledge is generated. The inability of Western IPRs to adequately cater to indigenous knowledge forms exists principally because the former are not designed for the protection of the latter. Throughout its evolution, conventional IP has not adverted itself to the

61. See id. at 223.

62. For perspectives on the epistemic question between allopathic and traditional medicine, see Chidi Oguamanam, Between Reality and Rhetoric: The Epistemic Schism in the Recognition of Traditional Medicine in International Law, 16 Sт. Thomas L. Rev. (forthcoming 2004). 
potential of its application to alternative epistemic narratives, ${ }^{63}$ thereby creating a crisis of legitimacy in the IP system.

The last decade has witnessed the resurgence of indigenous consciousness in the global constitutive process. More than the familiar battle cries of human rights and self-determination, protection of indigenous knowledge has become an integral part of the indigenous quest for survival. ${ }^{64}$ Only a few subjects can claim to be more topical than the knowledge question in the discourse of indigenous issues in contemporary international law. Because indigenous peoples have tied their quest for self-determination to their demand for cultural integrity, ${ }^{65}$ they are unequivocal that the modalities for the protection of their knowledge must be consistent with their worldview and the socio-cultural and economic contexts in which their knowledge is generated and practiced.

As part of the indigenous resurgence/renaissance, there has been a remarkable increase in the international solidarity of indigenous peoples through conferences, workshops, declarations and resolutions articulating indigenous positions on the subject of IPRs and the protection of indigenous knowledge in general. At best, these declarations have the status of soft law, ${ }^{66}$ being as it were, non-binding exhortations encouraging desired modes of state behavior. However, their influence in the normative process should not be discounted. Through these declarations, indigenous peoples have made suggestions (as opposed to generating juridical instruments) for normative options for the protection of traditional knowledge. ${ }^{67}$ Indigenous peoples have also either rejected or expressed their reservation over conventional IP. Generally, they are in agree-

63. For literature on the discourse of the origin and philosophy of IP, see generally GraHaM Dutfield, Intellectual Property Rights and the Life Sciences: A Twentieth Century History (2003); Peter Drahos, A Philosophy of Intellectual Property (1996); B.W Bugbee, Genesis of American Patent and Copyright Law (1967); Intellectual Property: Moral, Legal and International Dilemmas (Adam D. Moore ed., 1997); Hughes, supra note 24; Peter Drahos, The Universality of Intellectual Property Rights: Origins and Development, at http:// www.wipo.org (last visited Feb. 4, 2004) [hereinafter Universality of IPRs].

64. See Erica-Irene Daes, The Concepts of Self-Determination and Autonomy of Indigenous Peoples in the Draft United Nations Declaration on the Rights of Indigenous Peoples, 14 St. Thomas L. Rev. 259, 264 (2001); Elements of Sui Generis, supra note 22, at para. 14; Halewood, supra note 4, at 953; Blakeney, supra note 1, at 258 (noting that "[t]oday in Australia, indigenous peoples regard the protection of traditional knowledge as an issue of self-determination").

65. Blakeney, supra note 1 , at 258.

66. See Coombe, supra note 12, at 106-07.

67. See Blakeney, supra note 1 , at 256. 
ment over the integration of indigenous customary knowledge-protection protocols into the IP discourse.

A few notable regional initiatives with global ramifications, among several others ${ }^{68}$ illustrate this trend. The Mataatua Declaration on Cultural and Intellectual Property Rights of Indigenous Peoples is one of them. It was the first international conference of its kind. ${ }^{69}$ The Declaration associates the protection of indigenous knowledge with self-determination. ${ }^{70}$ It also recognizes, among other things, that the existing protection mechanisms are inadequate to safeguard the intellectual and cultural property of indigenous peoples. ${ }^{71}$ It calls for the promotion of "traditional practices and sanctions for the protection, preservation and revitalization of their [indigenous peoples'] traditional intellectual and cultural properties." 72

The second initiative is the 1994 International Consultation on Intellectual Property Rights and Biodiversity. The consultation was at the instance of the Co-ordinating Body of Organizations of Indigenous Peoples of the Amazon Basin (COICA). The COICA summit ${ }^{73}$ endorsed the Mataatua Declaration.

68. Some of them are: the recently concluded U.N. Conference on Indigenous Peoples and Information Society, Dec. 10-12, 2003; the Penang Conference, Feb. 1992, which formulated the Charter of Indigenous-Tribal Peoples of Tropical Forests (CIPT); the World Conference of Indigenous Peoples on Territory, Environment and Development, Kori-Oca, Brazil, May 1992, which authored the Indigenous Peoples Earth Charter. See Michael Blakeney, Bioprospecting and the Protection of Traditional Medical Knowledge of Indigenous Peoples: An Australian Perspective, 19 Eur. Intell. Prop. Rev. 298, 301-03 (1997); see also Michael Blakeney, Ethnobiological Knowledge and Intellectual Property of Rights of Indigenous Peoples in Australia, in IP AND ETHNOBIOLOGY, supra note 51, at 94 [hereinafter Ethnobiological Knowledge].

69. Convened by the nine indigenous nations of Mataatua in the Bay of Plenty Region of Aotearoa, New Zealand in June 1993. See Ethnobiological Knowledge; see also Michael Blakeney, The International Framework of Access to Plant Genetic Resources, in IP AND Ethnobiology, supra note 51, at 16 [hereinafter International Framework]. See generally, PoseY \& Dutrield, supra note 16.

70. Blakeney, supra note 1, at 258; see also Michael Blakeney, Intellectual Property in the Dreamtime-Protecting Cultural Creativity of Indigenous Peoples, Electronic J. Intell. Prop. Rts. (Nov. 9, 1999), at http://www.oiprc.ox.ac.uk/EJWP1 199.html (last visited Nov. 14, 2002).

71. The Mataatua Declaration on Cultural and Intellectual Property Rights of Indigenous Peoples, June 18, 1993, art. 1.1, available at http://www.tebtebba.org/tebtebba_files/susdev/ik/ mataatua.html.

72. Id. at art. 1.6.

73. Intellectual Property Rights and Biodiversity: The COICA Statement, available at http:// users.ox.ac.uk/ wgtrr/coica.htm (last visited Sept. 14, 2002) [hereinafter The COICA Statement]. 
COICA is radically critical of the dominant Western conception of IP. The summit makes perhaps the most scathing remarks yet regarding conventional IPRs. It falls short of calling for their outright rejection by indigenous peoples. In part I, Article 8 of the COICA statement declares that:

Prevailing intellectual property systems reflect a conception and practice that is:

colonialist, in that the instruments of developed countries are imposed in order to appropriate the resources of indigenous peoples; racist, in that it belittles and minimizes the value of [indigenous] knowledge systems;

usurpatory, in that it is essentially a practice of theft. ${ }^{74}$

COICA warns against the distortion of indigenous knowledge systems as a way to bring them into conformity with the existing IP regimes. ${ }^{75}$

Nineteen ninety-five witnessed the South Pacific UNDP Regional Consultation on Indigenous Peoples and Intellectual Property Rights. ${ }^{76}$ Its final statement echoed the Mataatua and COICA sentiments. In 1998, the First International Congress of Ethnobiology issued the Declaration of Belem, Brazil, urging "strong action" for the protection of indigenous knowledge." In 1999 at Seattle, indigenous peoples issued the Indigenous Peoples Seattle Declaration on the occasion of the Third Ministerial Meeting of the WTO in a similar vein. ${ }^{78}$

74. Id.; International Framework, supra note 69, at 16; Blakeney, supra note 1, at 261.

75. See The COICA Statement, supra note 73, at art. 9.

76. Held in Suva, Fiji, in April 1995. Final Statement on UNDP Consultation on Indigenous Peoples and Intellectual Property Rights, at http://users.ox.ac.uk/ wgtrr/suva.htm (last visited Sept 14, 2002).

77. Text of the Declaration of Belem, at http://users.ox.ac.uk/ wgtrr/belem.htm (last visited Sept. 12, 2002).

78. The disrupted 1999 Seattle Ministerial Conference was to focus on the review of the controversial article 27.3(b) of the TRIPs Agreement dealing with intellectual property rights on "nonconventional knowledge systems" and the patentability of life forms. Indigenous peoples seized the moment to restate their opposition to patenting sacred "life forms and life creating processes." Text of the Seattle Declaration, at http:/www.gfbv.de/ (last visited Sept. 14, 2002). Indigenous concerns assisted in fashioning the 2001 Doha Declaration of the Fourth Ministerial Conference of the WTO, which issued a guideline for the review of Article 27 of TRIPs. See Charles R. McManis, Intellectual Property, Genetic Resources and Traditional Knowledge Protection: Thinking Globally, Acting Locally, 11 Cardozo J. Int'L \& Comp. L. 547, 551 (2003). 
These declarations and statements are collectively re-enforcing. The common threads that run through all of them include the following: the entitlement of indigenous peoples to IPRs over their knowledge as an aspect of indigenous cultural identity and self-determination; skepticism toward Western forms of IPRs; the need for other means of reward and recognition of indigenous knowledge; the sacred spiritual bond between indigenous peoples, their biological diversity and relationship with their land and natural environment; the rejection of, or reservation over the patentability of, life forms.

A number of developments at policy level in the international arena have heeded the indigenous quest for a knowledge-protection mechanism that is sensitive to indigenous cultural identity and epistemology. The Convention on Biological Diversity (CBD), and the World Intellectual Property Organization (WIPO) have taken the moral high ground over other relevant institutions in this quest. ${ }^{79}$ Both organizations have opened preliminary conversations and initiatives toward the integration of indigenous knowledge-protection protocols into the IP debate.

Pointedly, Article 8(j) of the CBD, described by analysts as the core of the Convention, ${ }^{80}$ sets the stage in the direction of integrating indigenous knowledge-protection protocols into the IP conversation. Couched in the form of a guideline, Article $8(j)$ requires parties to " $[R]$ espect, preserve and maintain knowledge, innovations and practices of indigenous and local communities embodying traditional lifestyles ... and promote their wider application with the approval and involvement of holders of such knowledge ...." Implementation of this Article has remained the priority of the CBD from 1994 to present. ${ }^{81}$ The CBD explores

79. For example, UNCTAD, UNESCO, FAO, UNDP, IFF, ILO, WHO, among several others.

80. In his statement at the Second Open-Ended Inter-Sessional Working Group on Article 8(j) and Related Provisions of the Convention on Biological Diversity, Montreal Canada, February 48, 2002, Reuben Olembo, President of the Conference of Parties Meeting reiterated that: "the implementation of article 8(j) was one of the major challenges raised by the Convention on Biological Diversity." See CBD Doc. WG8J2, CBD, available at http://www.biodiv.org/ (last visited Sept 26, 2002).

81. In 1994, the Conference of Parties opened discussion over the implementation of Article 8(j). See Knowledge Innovations and Practices of Indigenous and Local Communities: Implementation of Article 8(j), Note by the Executive Secretary of the CBD for the Third COP, Nov. 4-15, 1996, $\mathrm{UNEP} / \mathrm{CBD} / \mathrm{COP} / 3 / 19$, available at http:/www/biodiv.org/ (last visited May 16, 2000; site now discontinued). So far, the Working Group has had three meetings. The first meeting was held in Seville, Mar. 27-31, 2000; the second meeting was held in Montreal, Canada, Feb. 4-8, 2002, and 
the details for the implementation of Article 8(j) through the Working Group on Article 8(j) and Related Provisions ${ }^{82}$ (WG), established by Decision IV/9 of the Convention's governing body, the Conference of Parties (COP). ${ }^{83}$ The WG is charged with, among other things, providing legal advice with regard to evolving legal or other mechanisms for the protection of indigenous knowledge. ${ }^{84}$ The WG has generated a list of principles through which it conducts its work. ${ }^{85}$ In sum, these principles prioritize the value and holistic nature of indigenous knowledge, its cultural context and the participation of indigenous peoples in the work of the WG. ${ }^{86}$ The recently established U.N. Permanent Forum on

the third meeting was held in Feb. 2004 in Kuala Lumpur, Malaysia. The complexity of its mandate compels the Group to adopt a multifaceted approach to the implementation of Article $8(j)$. For example, because of the cross-cutting issues arising in relation to Article 8(j), the Working Group initiated a program for the integration of the relevant tasks of its program of work into the thematic program of the Convention. The Executive Secretary prepared a progress report on integration (UNEP/CBD/WG8J/2/2) that was transmitted to the 6th COP after amendments (UNEP/CBD/WG8J/2/L.2) at the Group's plenary sessions. For similar reasons, the Working Group opted for a phased implementation of its mandate. The Group outlines its mandate into two phases. The first phase comprises seven key elements designed to activate and mobilize all the stakeholders implicated in Article 8(j), as well as to generate appropriate guidelines and legal assistance in support of implementation of Article 8(j). The second phase is concerned with longterm objectives. However, from its activities so far, it is apparent that the WG has set the tone in the direction of an in ward approach toward traditional knowledge for the purpose of Article 8(j) provisions. See Annex to Decision IV/9 of the Fourth COP, Program of Workon the Implementation of Article 8(j) and Related Provisions of the Convention on Biological Diversity, CBD, at http:// www.biodiv.org/ (last visited Sept. 26, 2002).

82. This additional mandate gives the WG wider powers. Since Article $8(j)$ is considered the nerve center of the Convention, many other provisions are related to it, not the least of them are those dealing with access to genetic resources and IPRs.

83. Held in Bratislava, Slovak Republic, May 1-15, 1998.

84. See COP Decision IV/9 para. 1(a), CBD, at http://www.biodiv.org/ (last visited Jun. 11, 2003).

85. Id.

86. Id. For example, item six of the second meeting of the WG considered a note by the Executive Secretary of the CBD on Participatory Mechanism on Indigenous and Local Communities (UNEP/CBD/WG8J2/4). A finalized draft on this item proposed by the Sub-Working Group at the 4th Plenary Session (UNEP/CBD/WG8(J)/2/L.6) was transmitted to the 6th COP. It is remarkable that the Group gives strong consideration to the sub-national and customary traditions for the protection of knowledge. See Report of the Ad hoc Open-ended Inter-sessional Working Group on Article 8(j) and related provisions of the Convention on Biological Diversity on the 
Indigenous Issues (PFII) ${ }^{87}$ is now in working communication with the WG. ${ }^{88}$ The Sixth COP specifically charged the WG to address the issue of a sui generis system for traditional knowledge protection. In regard to the integration of indigenous knowledge-protection protocols, the WG was required to compile and assess existing indigenous, local, national, and international sui generis systems. $^{89}$

The Sixth COP adopted the outline of the composite report on the status and trends of indigenous knowledge practices relating to sustainable uses and conservation of biodiversity. ${ }^{90}$ That effort is concerned with the status of traditional conservation knowledge and practices in indigenous and local communities. Relevant to the present discussion is the first phase of this initiative which focuses on traditional knowledge regarding food, medicine, conservation and use of flora and fauna, and those relating to major ecosystems. ${ }^{91}$ While adopting the outline of the composite report, the COP acknowledged "that indigenous

work of its second meeting, UNEP/CBD/COP/6/7, available at http://www.biodiv.org/meetings/ cop-06.asp (last visited June 11, 2003). Item seven of that meeting was devoted to "[a]ssessment of the effectiveness of existing sub-national, national and international instruments particularly intellectual property rights instruments that may have implications for the protection of the knowledge, innovations and practices of indigenous and local communities."

87. The PFII is a subsidiary organ of the Economic and Social Council of the United Nations. It serves as an advisory body on indigenous issues in the context of the Council's mandate relating to economic and social development, culture and the environment, and education and human rights. See John Carey \& Siegfried Wiessner, A New United Nations Subsidiary Organ: The Permanent Forum on Indigenous Issues, ASIL Insights (Apr. 17, 2001), at http:/www.asil.org/insights/ insigh67.htm (last visited Feb. 10, 2004).

88. See Recommendations of the Permanent Forum on Indigenous Issues to the Convention on Biological Diversity, U.N. Doc. UNEP/CBD/WG8J/3/8, at 2 (Sept. 28, 2003) (recommending "the establishment of an international ethical code on bio-prospecting in order to avoid bio-piracy and ensure the respect for indigenous cultural and intellectual heritage"), available at http:// www.biodiv.org (last visited Feb. 10, 2004).

89. The 6 th COP presented this request to the WG in response to the WG Report.

90. See Convention on Biological Diversity, COP Decision VI/10 on Article 8(j), Outline of Composite Report on the Status and Trends Regarding the Knowledge, Innovations and Practices of Indigenous and Local Communities Relevant to the Conservation and Sustainable Use of Biodiversity, and the Plan and Timetable for Its Preparation, Annex I para. 18, U.N. Doc. UNEP/SCD/COP/6/20 [hereinafter Composite Report], available at http://www.biodiv.org (last modified Jan. 23, 2004).

91. The listed categories are forests, dryland and steppes ecosystems, marine and coastal ecosystems, island ecosystems, mountain and valley ecosystems, inland waters and arctic ecosystems. See Composite Report, supra note 90, para. 2. The research will aim at emphasizing the need to respect, preserve and maintain traditional knowledge, innovation practices, and the capacity of indigenous and local peoples to protect local knowledge. 
peoples and local communities have their own systems for the protection and transmission of traditional knowledge as part of their customary law." 92 The report recognized that indigenous peoples are the appropriate authorities in matters relating to the protection of their knowledge..$^{93}$ The efforts of both the WG and the COP so far reflect a clear understanding on the need to draw in preexisting customary mechanisms at local levels for the preservation of the integrity of indigenous knowledge into the IP discourse.

The WIPO is another policy front on which an indigenous knowledgeprotection protocol is being explored for adoption as an integral part of the IP debate. In the last six years, the WIPO established the Global Intellectual Property Issues (GIPI) Division ${ }^{94}$ for the implementation of the GIPI program. ${ }^{95}$ That program articulates and implements WIPO's response to contemporary issues relevant to IP, including the challenges posed by traditional and cultural knowledge. As part of the GIPI program, in 1998-99, WIPO conducted global fact-finding missions that explored the IP needs and expectations of traditional knowledge holders as an attempt to provide the relevant background for policy initiatives on IP. ${ }^{96}$ Through the missions, indigenous peoples across the globe narrated their different customary protocols for knowledge-protection. They demanded that indigenous knowledge protection be premised on the customary tools for knowledge protection existing in indigenous communities. ${ }^{97}$ The WIPO mission identified three different informal customary protocols for knowledge protection in indigenous communities. These included trade regimes over traditional designs, songs and dances; ritual regimes for the protection of traditional medicinal knowledge; and customary laws on the use of traditional images and artistic works. ${ }^{98}$

92. See id.

93. Composite Report, supra note 90, para. 25.

94. This initiative was at the instance of the then-newly-elected Director General of WIPO, Dr. Kamil Idris.

95. See generally Main Program 11, Global Intellectual Property Issues, WIPO Doc. A/34/2/WO/ $\mathrm{PBC} / 1 / 2$ (implementing a method for identifying technological and social changes that affect the current intellectual property system and proposing ways to mitigate these pressures) [hereinafter Main Program 11 ], available at http://www.wipo.org (last visited Feb. 14, 2004). Although established in 1997, the GIPID was empowered by the 1998-99 biennial budget of WIPO. Its mandare has been reviewed and renewed on a biennial basis thereafter.

96. See FFM, supra note 1 , at 5 .

97. See id. at 76

98. See id. at $57-65$. 
With regard to trade regimes, the Canadian Bloodtribe has a sophisticated and flexible customary protocol in songs, dancing, and ceremonies related to the creation of tipi designs, its licensing and transfers. In South Asia, intellectual property for the protection of ayurvedic, siddha, unani tibbi, and non-codified medical systems take the form of rituals, magic, myths, and spiritual beliefs associated with the secrecy of traditional medicine. These protocols for knowledge protection have the effect of discouraging unlawful appropriation. In the Milpurrurru case, ${ }^{99}$ a federal court in Australia found that under the customary law of an Aboriginal community, artistic works are collectively owned. However, some sections of the community have exclusive right over the production of specific imageries. Strikingly, such a right to depict a design does not necessarily empower the designer to license or sanction the reproduction of the design. ${ }^{100}$

The need to articulate and study the protocols or regimes of knowledge protection in indigenous customary law and jurisprudence was identified in the WIPO missions as a key IP need and expectation of traditional knowledge holders. ${ }^{101}$ In the ongoing efforts in this direction, WIPO is involved in conducting feasibility studies on the applicability of customary laws and protocols toward the protection of local knowledge. WIPO acknowledges that the protection of traditional knowledge is a subject at the intersection of both customary and modern legal systems. ${ }^{102}$ This marks a shift in the dominant thinking that had hitherto reified conventional IP as the only mechanism for knowledge protection.

The Inter-Governmental Committee on Genetic Resources, Traditional Knowledge and Folklore (IGC-GRTKF) ${ }^{103}$ is yet another platform under WIPO for the integration of indigenous knowledge. That committee was set up in 2000 as a forum for member states of WIPO to deliberate on a number of issues including protection of traditional knowledge and expressions of folklore. Among other things, the IGC has done a survey of existing forms of IP protec-

99. Milpurrurru v. Indofurn Pty. Ltd. (1994) 54 F.C.R. 240, (1995) 30 I.P.R. 209.

100. See Colin Glovan, Aboriginal Art and the Protection of Indigenous Cultural Rights, 7 Eur. Intell. Prop. Rev. 227 (1992).

101. See Main Program 11, supra note 95.

102. See FFM, supra note 1, at 234-35.

103. Established by the 26th session of WIPO General Assembly after the release of the report of the fact-finding missions at http://www.wipo.int./tk/en/igc/index.html (last visited Feb. 17, 2004). See McManis, supra note 78, at 557-58. 
tion for traditional knowledge. ${ }^{104}$ Its initiatives on folklore contribute to the ongoing process of re-appraisal ${ }^{105}$ of the WIPO-UNESCO Model Provisions on National Laws on Expressions of Folk lore Against Illicit Exploitation and Other Prejudicial Actions. ${ }^{106}$ The IGC held its fifth session in July 2003 and its

104. See Intergov'tal Comm. on Intell. Prop. and Genetic Resources, Traditional Knowledge and Folklore, Survey on Existing Forms of Intellectual Property Protection for Traditional Knowledge, WIPO Doc. WIPO/GRTFK/IC/2/5 (Aug. 8, 2001), available at http://www.wipo.int/tk/en/ index.html (last visited Feb. 17, 2004).

105. Even though the Model Provisions have been incorporated into the copyright laws of some developing countries, they are perceived as inadequate with regard to aspects of indigenous knowledge forms even in those countries that have voluntarily adopted them. In addition, there is a need at WIPO, and especially among developing countries, to review the Model Provisions by taking into account developments and new forms of commercial exploitation of traditional knowledge that have taken place since 1982 when the Model Provisions were introduced. The 1997 UNESCO/ WIPO World Forum on the Protection of Folklore, which was held in Phuket, Thailand, April 810 , adopted a plan of action for the revision of the Model Provisions. Consequently, WIPO has, since 1999, beginning in Pretoria, South Africa, organized four regional consultations on the protection of expressions of folklore. Other Conferences were held in Vietnam, Tunisia and Ecuador to set the stage for the revision of the Model Provisions. See United Nations Educational, Scientific, and Cultural Organization, Protection of Folklore, UNESCO-WIPO African Regional Consultation on the Protection of Expressions of Folklore, at http://www.unesco.org/culture/copyright/folklore/html_eng/ pretoria.shtml (last visited Feb. 17, 2004); see also Ralph Oman, Copyright-Engine of Development: An Analysis of the Role of Copyright in Economic Development and Cultural Vitality, at http:// upo.unesco.org/pdf/Copyright.pdf (last visited Feb. 17, 2004).

106. See UNESCO-WIPO Model Provisions, supra note 31, at 62-65. A part from the CBD and WIPO's GIPI project, the Model Provisions is another instrument that addresses the subject of protection of local knowledge. It has a limited emphasis on a yet limited and controversial subject-folklore. In addition, attempts to elevate the WIPO-UNESCO Model Provisions to the status of international covenant have not yielded any results. To date, the United Nations, and indeed most developed countries, have yet to adopt the Model Provisions. Nevertheless, the latter has provided the basis for modern copyright regimes in a number of African countries including Nigeria, Ghana, Angola, Gabon, the Democratic Republic of Congo, Malawi and Tunisia. See generally Folarin Shyllon, Conservation, Preservation and the Legal Protection of Folklore in Africa: $A$ General Survey, Copyright Bull. 32, No. 4 1998, at 37 (discussing the evolution of copyright protection of folklore in African countries). As part of its work on folklore, the IGC-GRTKF has generated a questionnaire evaluating national experiences on the protection of folklore in relevant countries. See Intergov'tal Comm. on Intell. Prop. and Genetic Resources, Traditional Knowledge and Folklore, Questionnaire on National Experiences With the Legal Protection of Expressions of Folklore, WIPO Doc. WIPO/GRTFK/IC/2/7 (June 22, 2001), available at http://www.wipo.org (last visited Feb. 17, 2004). 
recommendations were then submitted to the WIPO General Assembly. ${ }^{107}$ All of these activities, both at the WIPO (including the IGC-GRTKF) and the CBD (including the WG), are conducted in deliberate collaboration amongst these bodies in a manner designed to eschew conflicted outcomes. ${ }^{108}$ Both WIPO and the CBD have shown a commitment to extending the searchlight on an appropriate mechanism for local knowledge protection in the direction of prevailing and pre-existing knowledge-protection protocols in indigenous or non-Western

107. See Intergov'tal Comm. on Intell. Prop. and Genetic Resources, Traditional Knowledge and Folklore, Report of the Fifth Session, WIPO Doc. WIPO/GRTKF/IC/5/15 (Aug. 4, 2003), available at http://www.wipo.int (last visited Feb. 17, 2004). Item 4 of the Report deals with folklore. Id. at 27-59. Item 5 of the Report covers traditional knowledge, and includes the following: an IP toolkit for traditional knowledge documentation; technical proposals on databases and registries of traditional knowledge; existing IP protection for traditional knowledge; and elements of sui generis systems for protection of traditional knowledge. Id. at 60-110. There is a correlation between the activities of the IGC-GRTKF and the WG on Article 8(j). The Fifth Session was originally scheduled to be the last for the IGC, but with the extension of its term, the activities of the IGC remain ongoing. The Sixch Session is scheduled for Mar. 15-19, 2004.

108. In 1994, the COP proposed the idea of a memorandum of understanding between the CBD and the WIPO as early as 1994. The following decisions of the COP indicate the extent of the collaboration: Decision III/14 of the Third Meeting of the Conference of the Parties to the Convention on Biological Diversity, para. 4 (which "[r]equests the Executive Secretary to remain informed as to relevant international processes and bodies, including, inter alia ... the World Intellectual Property Organization ..."), available at http://www.biodiv.org (last modified Jan. 23, 2004); Decision IV/9 of the Fourth Meeting of the Conference of the Parties to the Convention on Biological Diversity, para. 9 (preamble) ("[f]urther recognizing the importance of making intellectual-property-related provisions of Article $8(j)$ and related provisions of the Convention on Biological Diversity and provisions of international agreements relating to intellectual property mutually supportive, and the desirability of undertaking further cooperation and consultation with the World Intellectually Property Organization"); para. 10 (preamble) ("[w]elcoming the decision of the World Intellectual Property Organization to incorporate biodiversity-related issues under its 1998-1999 main programme item 11 ('Global intellectual property issues')"); para. 14 (requesting "the Executive Secretary to transmit to the secretariat of the World Intellectual Property Organization, decisions and documents of the fourth meeting of the Conference of the Parties and to apply for observer status in the World Intellectual Property Organization, for the purpose of representing the Convention on Biological Diversity in meetings related to main programme 11.1 and 11.2 of the Organization"), available at http:/www.biodiv.org/(last modified Jan. 23, 2004). In Decision VI/10 on Article 8(j) and Related Provisions para. 11 (preambular statement), the COP acknowledged the mandate of the IGC. Composite Report, supra note 90 . The COP enlists the IGC in the project of assessing the effectiveness of prevailing intellectual regimes in the protection of indigenous knowledge. For example, in para. 31 the COP "[i]nvites the Intergovernmental Committee on Intellectual Property and Genetic Resources, Traditional Knowledge and Folklore of the World Intellectual Property Organization to continue its efforts to promote the more effective participation of indigenous and local communities in its work." $1 d$. 
cultures. According to Coombe, "WIPO and the CBD have recognized that indigenous customary law has to be respected when considering the use of traditional knowledge and that indigenous customary law principles provide legitimate juridical resources for a consideration of alternative forms and norms of property." ${ }^{109}$ The discernible principle in these trends is that they place indigenous peoples in a position to play a major role in "articulating an alternative vision for intellectual property rights." 110 This is in a manner that has the potential to re-direct attention from the focus on conventional IP regimes to indigenous customary knowledge-protection schemes. ${ }^{111}$

\section{Integration as Localization: The Challenge of Globalization}

From its historic roots in Europe, Western IP has spread across the globe in three stages. ${ }^{112}$ Peter Drahos identifies the stages as the territorial, the international, and the global periods. ${ }^{113}$ In the territorial epoch, IPRs were construed as having a strictly municipal application. They never extended beyond the jurisdiction of the granting sovereign. The international period, which commenced in Europe in the late nineteenth century, was characterized by bilateral and multilateral agreements that endorsed mutual reciprocity in the protection of IPRs in the works of nationals of contracting states. The third period "has its origins in the linkage that the United States... made between trade and intellec-

109. Coombe, supra note 6, at 284.

110. Id. at 285.

111. However, the question is how far these policy debates would go, or how sustainable they become in light of the many competing considerations that pull toward conventional IPRs? Such considerations include the controversial idea of an indigenous knowledge database, which is perceived in some circles as not being a cross-cultural model because it facilitates the documentation or formalization of indigenous knowledge suited to conventional intellectual property. See Intergov'tal Comm. on Intell. Prop. and Genetic Resources, Traditional Knowledge and Folklore, Inventory of Traditional Knowledge-Related Periodicals, WIPO Doc. WIPO/GRTKF/IC3/5 (discussing perspectives on the indigenous knowledge database) (Apr. 30, 2002), available at http:// www.wipo.org (last visited Feb. 17, 2004); see also supra note 104 and accompanying text. See the details of the Third IGC-GRTKF session (June 13-21, 2002), at http://www.wipo.org (last visited Feb. 17, 2004) and the details of the Fourth IGC-GRTKF session (Dec. 9-17, 2002), at http:// www.wipo.org (last visited Feb. 17, 2004).

112. See Universality of IPRs., supra note 63, at 3. See generally Drahos \& BRAITHWaITE, supra note 13 (discussing the evolution of the TRIPs agreement into an agreement that now largely governs IP disputes across the globe).

113. Universality of IPRs, supra note 63, at 3. 
tual property in the 1980s, a linkage which emerged at a multilateral level in the form of the [WTO] Agreement on Trade-Related Aspects of Intellectual Property Rights, 1994." 114 The TRIPs Agreement thus marks a major transition from the national character of IP into a globally regulated subject matter. The irony is that before the TRIPs Agreement, IP was considered a subject within the impeachable jurisdiction of national governments. The latter had unfettered powers to determine items deserving IPRs protection, including the scope, nature, duration, and so on, attaching to those rights. All of these powers are now circumscribed under the TRIPs Agreement. ${ }^{115}$ TRIPs did not, however, completely obliterate the national character of IP.

The TRIPs Agreement marks the crystallization of the global phase of IPRs. Previous efforts at the globalization of IPRs were selective in terms of the applicable categories, and less comprehensive both in the scope of their coverage and the number of contracting parties. ${ }^{116}$ These earlier treaties did not have the luxury of a global and ideological superstructure for administration and enforcement, such as the WTO of which TRIPs is a component. Perhaps in terms of timing, coming in the post-Cold War and globalization era, the TRIPs Agreement's agenda for a global (Western) IP hegemony ${ }^{117}$ makes it "the only game in town" 118 as far as IPRs are concerned. The TRIPs Agreement was birthed at the highpoint of our extant knowledge-based global economic and information society. The hallmarks of these phenomena include an exponential increase in digital technology and life sciences-related technological breakthroughs, also referred to as the "bio-revolution."

114. Id, See generally Dutfield, supra note 63 (discussing the role of IP rights in international trade, the global economy, and international relations).

115. According to Coombe, many scholars believe that "TRIPS has so completely limited the capacities of member States to adjust IPRs to meet social policies objectives," especially in relation to conservation of biodiversity. See Coombe, supra note 12, at 91-92.

116. The two principal multilateral intellectual property treaties that marked initial attempts at globalization of intellectual property rights were the Paris Convention for the Protection of Industrial Property, 1883, as revised in Stockholm on July 14, 1967, reprinted in 21 U.S.T. 1583, 828 U.N.T.S. 305; the Berne Convention for the Protection of Literary and Artistic Works, Sept. 9, 1886 (as revised by the Paris Act on July 24, 1971), reprinted in 25 U.S.T. 1341, 828 U.N.T.S. 221, available at http://www.law.cornell.edu/treaties/berne/overview.html (last visited Feb. 17, 2004).

117. For the negotiation and history of the TRIPs Agreement, including the influence of the United States, the European Union, and Japan in the Uruguay Rounds of the General Agreement on Trade and Tariffs (GATT), see Daniel Gervais, The TRIPS Agreement: Drafting History and Analysis (1998).

118. Horton, supra note 14 , at 27-28. 
TRIPs therefore represents an IP handmaiden groomed for the service of globalization and internationalization of markets. Conventional narrative depicts globalization as a triple process of economic, social, and political transnationalization. ${ }^{119}$ It facilitates or is facilitated by a centralized regulatory scheme in a number of spheres including economic, social, human, natural, and material resources. Globalization depicts structural changes in transitional structures within the rubric of capitalism. ${ }^{120}$ In the knowledge-based, digital and information society, IP plays a very crucial role. Within the logic of globalization, TRIPs as a centralized or global regulatory regime on IP could be perceived as a necessity, especially in relation to international globalization and opening of markets. The shrinking of state sovereignty over IPRs became inevitable in order to yield a more extensive and pervasive IP regime whereby weaker states are circumscribed in their ability to deploy IP protection to foster peculiar national interests. The international arena, dominated by stronger players, especially the United States and its allies, became the appropriate site for the regulation of IP.

Given that the inquiry into indigenous knowledge-protection protocols is centrifugal in orientation, how does it fit into the global direction of IPRs as reflected by the TRIPs Agreement? Put another way, is the inquiry into indigenous customary regimes on knowledge protection at cross purpose with the globalization phenomenon, especially in the IP arena? It seems that the way we interpret the globalization syndrome, the context of the integration initiative, and the extent of TRIPs erosion of the national status of IP will all assist in providing an informed answer to this question.

Outside of its oft-emphasized homogenizing character, ${ }^{121}$ a balanced view of globalization characterizes it as a conflicted phenomenon that has generated what is described as one of "the crucial interpretive dilemmas of our time." 122 There is no doubt that globalization has accentuated homogenization in its

119. See Boaventura de Sousa Santos, Toward a New Common Sense: Law, Science and Politics in the Paradigmatic Transition 253 (1995); see also id. at 250-377 (attempting an interpretive analysis of the contemporary phenomenon of globalization, describing its complex and multifaceted features from economic, social, political, cultural, religious, and legal dimensions).

120. See id. at 258-59.

121. De Sousa Santos calls this perception "globalization as homogenization or uniformization." Id. at 253. See William Twining, Globalisation and Legal Theory 4-5 (2000); see also Anthony Gidpens, The Consequences of Modernity 64 (1990). See generally Globalisation and the Third World (Ray Kiely \& Phil Marfleet eds., 1998).

122. See DE Sousa Santos, supra note 119, at 260. 
diverse ramifications: economic, social, political, industrial, informational, cultural assimilation and erosion, migration pattern, other forms of transnationalization, and so on. Conversely, it has heightened an unprecedented global networking of hitherto uncoordinated interests and coalitions. It has yielded the flourishing of alterity, especially in the cultural expression and resistance of indigenous and/or minority cultures to forces of domination or homogenization, ${ }^{123}$ including the blossoming of what a prominent scholar calls the "cosmopolitan alternative." 124

The desire of indigenous peoples to contribute to an alternative vision of IPRs should be seen in the context of the wave of indigenous renaissance in the global constitutive process. Indigenous peoples have linked their quest for selfdetermination to the protection of their knowledge, ${ }^{125}$ thus making knowledge the new frontier of the indigenous question in international law. Since 1992, beginning with the set of international environmental instruments articulated in Rio, ${ }^{126}$ indigenous peoples have become active participants in policy decisions that affect them. As a testament and highpoint of their activism, there is now the

123. See generally Will Kymlicka, Liberalism, Community and Culture (1989) (stressing the fundamental and primary loyalty of peoples to their cultural memberships in the face of centrifugal tendencies).

124. See Jeremy Waldron, Minority Cultures and the Cosmopolitan Alternative, in The Rights of Minority Cultures 93 (Will Kymlicka ed., 1995) (articulating cosmopolitanism as the virtual immersion or hybridization of cultures, the demise of homogeneity and loss of identity, purity, and claims to originality of any kind). But see De Sousa SANtos, supra note 119, at 264 (defining cosmopolitanism as "nothing more than the networking of local progressive struggles with the objective of maximizing their emancipatory potential in locu through translocal/ocal connections"); Ulf Hannerz, Cosmopolitans and Locals in World Culture, in Global Culture: Nationalism, Globalization and Modernity 237, 239 (Mike Featherstone ed., 1990) (appraising cosmopolitanism largely in terms of "openness toward divergent cultural experiences").

125. See Coombe, supra note 12, at 79; see also supra note 64 .

126. See generally United Nations Conference on Environment and Development: Rio Declaration on Environment and Development, U.N. Doc. A/CONF.151/5/Rev.1, reprinted in 31 I.L.M. 874,876 (1992) (reaffirming the principles the United Nations established to ensure the protection of the global environment and development of societies around the world); United Nations Conference on Environment and Development: Non-Legally Binding Authoritative Statement of Principles for a Global Consensus on the Management, Conservation and Sustainable Development of All Types of Forests, U.N. Doc. A/CONF.151/6/Rev.1, reprinted in 31 I.L.M. 882 (1992) (describing the need for a global consensus on the management of all forests) [hereinafter Forest Principles]; Convention on Biological Diversity, supra note 10, at 822 (noting the need for the preservation of biological diversity as a way to sustain natural habitats and maintain viable populations of species); United Nations 
U.N. Permanent Forum on Indigenous Issues. ${ }^{127}$ In addition, there is a pending expectation of an eventual United Nations Draft Declaration on the Rights of Indigenous Peoples. ${ }^{128}$ This document, now in $\mathrm{draft}$ form, articulates in a comprehensive manner, among other things, the importance of knowledge in the survival of indigenous peoples. ${ }^{129}$ The integration project is both the consequence and part of the logic of indigenous renaissance.

Indigenous successes in the twentieth century happened in the contexts of globalization and indigenous renaissance. Both phenomena are inextricably linked and reinforcing. Globalization, to some extent, empowers minority cultures and generates increased consciousness of cultural membership and identity. Indigenous renaissance and its impact on boosting various forms of cultural emancipation are incidences of globalization. In fostering homogenization, globalization also engenders resistance to domination and cultural appropriation ${ }^{130}$ which the integration initiative symbolizes. Cultural preservation and expression are platforms for resisting domination. ${ }^{131}$ Among the diverse ways in which globalization has enhanced indigenous emancipation and the integration project in the last five years is by facilitating a networking culture amongst

Conference on Environment and Development: Framework Convention on Climate Change, U.N. Doc. A/AC.237/18, reprinted in 31 I.L.M. 849 (1992) (recognizing that countries around the world should enact effective environmental legislation to counteract adverse global climate changes); United Nations: Convention to Combat Desertification in those Countries Experiencing Serious Drought and/or Desertification, Particularly in Africa, U.N. Doc. A/AC.241/15/Rev.3, reprinted in 33 I.L.M. 1332 (1994) (affirming the need to mitigate the effect of drought throughout the international community).

127. See supra note 87.

128. A Draft Declaration was prepared in 1993 by the United Nations Working Group on Indigenous Peoples (UNWGIP) and adopted in 1994 by the Sub-Commission on Prevention of Discrimination and Protection of Minorities. See United Nations Draft Declaration on the Rights of Indigenous Peoples, U.N. Doc. E/CN.4/Sub.2/1994/2/Add.1 (1994) (presently before the U.N. bureaucracy at the Sub-Commission on Human Rights).

129. A subsidiary document is dedicated to the cultural and intellectual property rights of indigenous peoples. See 1993 Study on the Protection of Cultural and Intellectual Property of Indigenous Peoples, U.N. Sub-Commission on Prevention of Discrimination and Protection of Minorities, 45th Sess., Agenda Item 14, U.N. Doc. E/CN.4/Sub.2/1993/28 (1993); see also Daes, supra note 17.

130. On the notion of cultural appropriation and resistance, see generally, СоомвE, supra note 35 (providing a legal enthnography of the ways in which intellectual property law shapes cultural politics in consumer societies).

131. According to De Sousa Santos, "culture is, if anything, a struggle against uniformity." DE Sousa SANtos, supra note 119, at 257. 
indigenous peoples across the globe. Coombe captures this trend in the following observation:

Strategic alliances are being forged between indigenous NGOs, North-South alliances of farmers' and peasants' groups, traditional healers associations, environmental NGOs, development institutions and activists.... These new coalitions form the core of a new and vibrant political movement organized around group opposition to existing intellectual property laws .... These new networks of advocates and activists are organized to put pressure on governments and United Nations bodies to insist upon new understanding of justice, equity, and accountability in the appropriation of genetic resources, traditional knowledge, and in the international exercise of and justifications for intellectual property rights. ${ }^{132}$

This trend has enabled the world's indigenous peoples to press forward in influencing the global constitutive process exemplified, for instance, by the elaborate debate on IP. Here, globalization fulfils one of its significant and less reckoned expectations, namely, generating "uncontrollable dangers" of "unsuspected emancipations." 133

Lastly, even though the TRIPs Agreement symbolizes globalization by prescribing minimum statutory conditions of IP for global application, it did not dispense with the national character of IPRs. TRIPs' encroachment on the rights of national governments is not absolute and should not be taken as foreclosed. ${ }^{134}$ For instance, under Article 27.2 of TRIPs, national governments have

132. Coombe, supra note 6 , at 278.

133. De Sousa Santos, supra note 119, at 261.

134. See, for example, Article 31 of the TRIPs Agreement, which restricts the powers of national governments over the use of compulsory licenses to, inter alia, access patented drugs; this is cited as one of TRIPs' far reaching changes. Although this view is quite correct, the restrictions imposed under Article 31 are not absolute. Article 31 provides for face-saving exceptions to such restrictions for instance, in cases of national public health emergencies as witnessed in the disagreement between the United States and South Africa concerning the latter's attempt to procure badly needed HIV/AIDs drugs by invoking Article 31 exceptions. For accounts and analyses of the US/ South Africa HIV/AIDs drug politics under the TRIPs Agreement, see the following: Winston P. Nagan, International Intellectual Property, Access to Health Care, and Human Rights: South Africa v. United States, 14 Fla. J. INT'L L. 155 (2002); Susan K. Sell, Post-TRIPS Developments: The Tension 
some leverage in determining the patentability of particular subject matters. That provision permits national governments to exclude from being patented inventions whose exploitation may be offensive to ordre public. Inventions that impinge upon indigenous cultural sensitivities have been linked to the ordre public exception under that provision. ${ }^{135}$ Since knowledge-protection protocols are products of the contexts and culture in which knowledge is generated, one unique aspect of such regimes is that they must of necessity be in harmony with indigenous cultural sensitivities.

On final a note, in the CBD's conception, even in its current lack of empirical details, the integration project is envisioned as a national initiative with potential global ramifications. ${ }^{136}$ It is expected to set the stage for a global framework for the protection of indigenous knowledge on the basis of indigenous conceptions, and as a global plan of action on how to conserve biological diversity. ${ }^{137}$ To this extent, the integration project may not be in any serious conflict with globalization, as it appears on first consideration.

\section{Conclusion}

Regimes for the protection of knowledge are products of the socio-cultural and epistemological environments in which knowledge is generated. Every culture has knowledge-protection mechanisms. Protecting traditional knowledge with western IP is possible at the price of forced epistemological assimilation of

Between Commercial and Social Agendas in the Context of Intellectual Property, 14 FLA. J. INT'L L. 193 (2002); James Thuo Gathii, Rights, Patents, Markets and the Global AIDS Pandemic, 14 FLA. J. INT'L L. 261 (2002). National governments need to be more audacious and creative in exploiting relevant sections of the TRIPs Agreement. Apart from the need to de-emphasize the notion that TRIPs has completely eroded the powers of national governments, the linkage between IP and the human rights of indigenous peoples shows that the human rights front is an untapped arena at which national governments and indeed the international community can ensure "that IPRs serve larger goals of global social justice." See Coombe, supra note 12, at 115.

135. This argument has not been tested in any "biopiracy" patent opposition. In the celebrated cases of neem, turmeric, and ayahausca, the adjudicating bodies preferred the less controversial grounds, such as novelty of purported inventions/processes under which it was convenient to revoke some patents based on these plants.

136. For example, WIPO has suggested to the IGC-GRTKF that the latter has the option to focus on systems of protection at national levels (supposedly based on indigenous norms and protocols) with a view to framing more general principles in the form of an international framework. See Elements of Sui Generis, supra note 22, at para. 8.

137. See Composite Report, supra note 90, at para. 18. 
the former. This is evident from the illustration this article makes about traditional medicine and patents. As a centrifugal initiative, the ongoing effort to integrate indigenous customary knowledge-protection protocols into an alternative IP vision appears to be in conflict with extant globalization in the IP arena. A critical reading of the globalization phenomenon, particularly against the backdrop of indigenous renaissance in the twentieth century, suggests a converse impression. Although the cross-cultural outlook on IP may not conflict with globalization, it is an initiative at a nascent stage. Without doubt, it raises a number of questions, especially with regard to its empirical details, which are not explored in this article. The challenge of globalization to the integration project broached here is only one of the myriad questions arising from the quest for an alternative vision of IP that has just begun. 


\section{Link, Search, and Browse - FAST!! www.journals.uchicago.edu/JLS}

THE JOURNAL OF
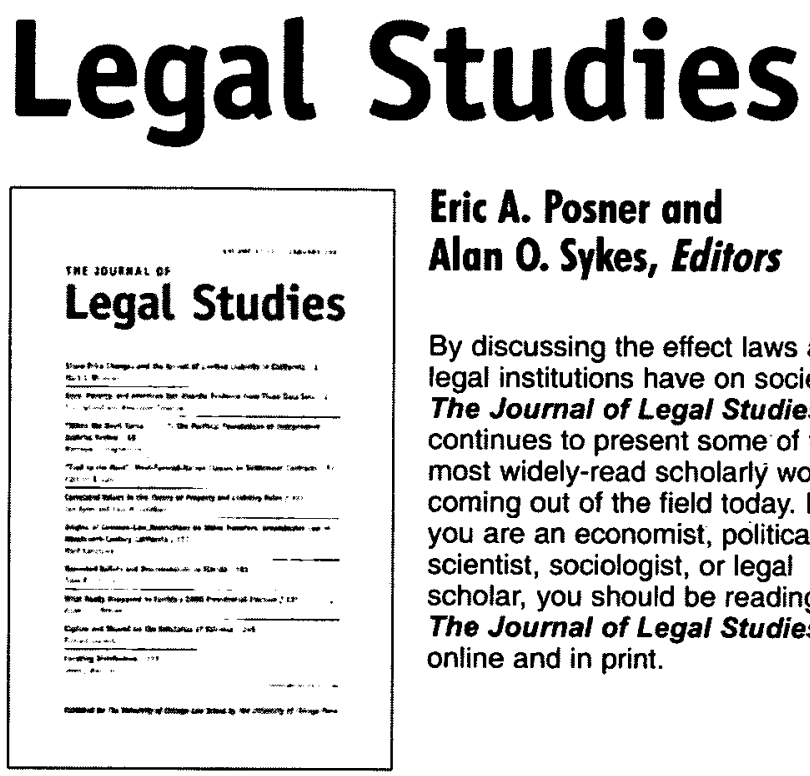

\section{Eric A. Posner and Alan 0. Sykes, Editors}

By discussing the effect laws and legal institutions have on society, The Journal of Legal Studies continues to present some of the most widely-read scholarly work coming out of the field today. If you are an economist, political scientist, sociologist, or legal scholar, you should be reading The Journal of Legal Studiesonline and in print.

\section{Save Valuable Research Time}

Sign up for our Tobles of Contents Alent

Whether you are a subscriber or not, sign up today for e-Toc, our e-mail alerting service delivering new content directly to you. Subscribe to the service at www.joumals.uchicago.edu/JLS. The e-mail will link to the issue as a whole. Abstracts may be viewed by subscribers and non-subscribers; links to individual articles are access controlled for subscribers and subscribing institutions.

The University of Chicago Press - Journals Division • P.0. Box 37005 - Chicago, IL 60637 